\title{
STUDI KOMPARASI PENGGUNAAN WHATSAPP DAN SCHOOLOGY TERHADAP HASIL BELAJAR DI MASA DARURAT
}

\author{
Miftahul Khair Abdul Muqsith ${ }^{1)}$, Husniyatus Salamah Zainiyati ${ }^{2)}$ \\ ${ }^{1}$ Pascasarjana, Universitas Islam Negeri Sunan Ampel Surabaya \\ email: abdulmuqsith440@gmail.com \\ 2 Pascasarjana, Universitas Islam Negeri Sunan Ampel Surabaya \\ email: husniyatussalamah@uinsby.ac.id
}

\begin{abstract}
This research aims to determine the differences between learning using Whatsapp and Schoology web-based sites learning. The method used in this research is a quantitative type of quasi experiment design with non-equivalent pretest \& postest group design. The sample in this study were students of Class X IPA 1 and Class X IPA 2. Data measurement is done by multiple choice tests with five answer choices and student questionnaires. The results of this research indicate that there are differences between class groups using Whatsapp and class groups using Schoology web-based sites learning, where class groups using Whatsapp have higher average scores than class groups Schoology web-based sites learning. This shows that Whatsapp media is more effectively to improve learning outcomes than Schoology web-based sites learning.
\end{abstract}

Keywords: Whatsapp, schoolgy, learning, emergencies.

\begin{abstract}
Abstrak: Penelitian ini bertujuan untuk mengetahui adanya perbedaan antara pembelajaran dengan menggunakan Whatsapp dan pembelajaran dengan situs berbasis web Schoology. Metode yang digunakan dalam penelitian ini adalah kuantitatif jenis quasi eksperiment dengan desain non-equivalent pretest \& postest group design. Sampel dalam penelitian ini adalah siswa kelas X IPA 1 dan siswa kelas X IPA 2. Pengukuran data dilakukan dengan tes pilihan ganda dengan lima pilihan jawaban dan angket (kuisioner) siswa. Hasil dari penelitian ini menunjukkan bahwa adanya perbedaan antara kelompok kelas menggunakan Whatsapp dan kelompok kelas dengan situs berbasis web Schoology, dimana kelompok kelas menggunakan Whatsapp memiliki hasil nilai rata-rata yang lebih tinggi dibandingkan kelompok kelas dengan situs berbasis web Schoology. Hal ini menunjukan bahwa media Whatsapp lebih efektif digunakan dalam meningkatkan hasil belajar daripada dengan pembelajaran dengan situs berbasis web Schoology.
\end{abstract}

Kata kunci: Whatsapp, schoolgy, pembelajaran, masa darurat.

\section{PENDAHULUAN}

Kejadian Luar Biasa (KLB) yang melanda dunia, termasuk Indonesia dalam hal ini adalah wabah pandemi global yang disebut wabah Covid-19 tentunya bukan harapan untuk terjadi. Berbagai rencana yang sebelumnya telah terencana dengan baik harus ditunda bahkan dibatalkan.
Misalnya saja, Ujian Akhir Nasiolan tinkat SMA dan SMP harus dibatalkan lantaran adanya pandemi Covid-19. Segala aktivitas pembelajaran yang seharusnya dilaksanakan di sekolah juga harus dialihkan menjadi pembelajaran di rumah lantaran hak para siswa untuk mendapatkan ilmu pengetahuan haruslah berlanjut di masa darurat seperti ini 
(Sanjaya, 2020). Adapun salah satu adaptasi yang dapat dilakukan dalam dunia pendidikan untuk mengatasi masalah tersebut adalah pembelajaran secara daring. Pengembangan pembelajaran berbasis IT harus dilakukan pihak sekolah dengan fasilitas yang tentunya memadai. Hal ini sangat erat kaitannya dengan pemilihan platform komunikasi yang memadai dan paling tepat digunakan media pembelajaran antara guru dan siswa (Nugroho, 2020). Pembelajaran seperti ini tentunya menjadi tantangan baru dalam proses pembelajaran, terlebih kaitannya dengan kuota internet yang terbatas dan sinyal internet yang tidak lancar bagi sebagian guru atau siswa.

Tantangan lainnya adalah dalam hal komunikasi antara guru dan siswa. Berbagai kanal percakapan seperti Whatsapp mesenger, video call, zoom dalam aktivitas pembelajaran harus terjalin dengan baik. Apabila tantangan-tantangan tersebut tidak teratasi dengan baik, hal tersebut dapat menjadi kendala tersendiri dalam pembelajaran, salah satunya dalam hal pengumpulan tugas. Dampaknya capaian pembelajaran tidak memenuhi syarat kriteria ketuntasan minimal (KKM). Perolehan nilai KKM yang kurang sudah seharusnya mendapatkan perhatian dari guru supaya siswa menguasai materi yang telah dipelajari (Teguh Pratikno \& Ewo Termedi \& Wahid Munawar, 2014).

Adapun materi yang dimaksud yaitu memahami unsur-unsur hadist pada mata pelajaran Qur'an Hadist di kelas X semester genap di Madrasah Aliyah Asy-Syakur Ngasem Bojonegoro. Dengan memanfaatkan teknologi atau aplikasiaplikasi tersebut diharapkan integrasi siswa dengan guru dalam hal pembelajaran semakin baik, flexibel dari segi ruang dan waktu.

Hal ini senada dengan tujuan revolusi industri 4.0 teknologi memiliki peran yang snagat penting. Terlebih pembelajaran abad 21 pemanfaatan teknologi dalam dunia pendidikan bukan sesuatu yang tidak mungkin. Sehingga, seorang guru dituntut untuk memahami prinsip penggunaan teknologi pendidikan dengan baik (Putrawangsa \& Hasanah, 2018). Salah satu media komunikasi yang banyak digunakan, baik oleh guru maupun siswa adalah Mobile Instant Messaging (MIM) berupa aplikasi Whatsapp. Beberapa penelitian yang telah dilakukan menunjukkan bahwa kelebihan aplikasi Whatsapp secara tidak langsung dapat meningkatkan interaksi sosial (Rambe \& Chipunza, 2013 ; Rambe \& Bere 2013). Irwandani (2016) melakukan sebuah survey yang menghasilkan bahwa sebanyak 98\% siswa memiliki akun sosial media berupa Facebook, Whatsapp dan Instagram. Pada penelitian lainnya mengungkapkan bahwa 97,24\% responden menyatakan pernah menggunakan WhatssApp dan 61,81\% menyatakan bahwa aplikasi Whatsapp merupakan aplikasi yang paling sering diunakan untuk berkomunikasi (Zebua, 2017). Salah satu alasan banyaknya Whatsapp digemari oelh para responden adalan karena aplikasi tersebut mempunyai banyak fitur yang bisa dimanfaatkan oleh guru dan siswa untuk berinteraksi dan berdiskusi dimanapun dan kapanpun (Nasrullah, 2015: 40). Hal ini membuat aplikasi Whatsaap snagat bisa dimanfaatkan di masa darurat pandemi seperti ini.

Seperti halnya Whatsapp, platform Schoology juga dapat digunakan untuk berinteraksid an berdiskusi antara guru dan siswa. Adaapun pada platform Schoology sendiri dirancang sedemikian rupa sehingga dapat digunakan sebagai media penilaian otomatis berbasis web. Situs Schoology memiliki keunggulan tersendiri dalam bidang pendidikan. Dimana dalam situs ini berusaha menggabungkan e-learning dan jejaring sosial sekaligus. Dalam sebuah pembelajaran di situs Schoology. untuk memasukkan nama siswa yang ikut di kelas guru hanya perlu memberikan kode kepada siswa-siswa yang diajarnya (Arsini, 2017).

Beberapa penelitian terkait penggunaan aplikasi di gadget dapat membuat siswa memahami isi teks bacaan lebih mudah (Gheytasi et al., 2015). Penelitian lain menunjukkan teknologi online mampu memberi kontribusi dalam menimplementasikan pembelajaran kontruktivismeyang cukup tepat sebagai acuan pembelajaran secara daring (Muclas, 2016). Adapun penelitian terkait aplikasi Whatsapp menunjukkan bahwa Whatsapp 
menyediakan kesempatan bagi guru untuk memberikan pelayanan bagi siswa untuk berinteraksi secara bermakna (Naidoo \& Kopung, 2016). Selain itu, penggunaan aplikasi Whatsapp mampu mendorong siswa berkomunikasi secara aktif dan kolaboratif dalam kegiatan pembelajaran (Sholihatin dkk., 2019). Manfaat penggunaan aplikasi Whatsapp dalam pembelajaran bahwa group Whatsapp memberikan fasilitas pembelajaran secara kolaboratif antara guru dan siswa maupun sesama siswa baik di sekolah maupun di luar sekolah untuk berbagi banyak hal serta memberikan kemudahan dalam memberikan pengumuman maupun mempublikasikan karya atau tugas siswa (Indaryani, 2018). Berdasarkan kelebihan dan kekurangan yang dimiliki masing-masing platform antara Whatsapp dan Schoology maka penulis ingin melakukan penelitian terkait penggunaan media pembelajaran tersebu apakah memiliki perbedaan pula terhadap hasil belajar siswa dalam materi memahami unsur-unsur hadist adapun penelitian ini bertujuan untuk mendeskripsikan perbedaan antara penggunaan platform tersebut dalam pembelajaran. Sehingga rumusan masalah dalam penelitian ini adalah apakah terdapat perbedaan antara penggunaan Whatsapp dan Schoology terhadap hasil belajar dalam materi memahami unsur-unsur hadist di masa darurat pandemi.

\section{METODE PENELITIAN}

Metode yang digunakan dalam penelitian ini adalah kuantitatif menggunakan jenis penelitian quasi eksperiment dengan desain non-equivalent pretest \& postest group design, dimana subyek dalam penelitian terdapat dua kelompok kelas yang terdiri atas kelompok kelas dengan menggunakan Schoology dan kelompok kelas yang menggunakan aplikasi Whatsapp. Adapun penentuan kelas tersebut tidak dipilih secara acak melainkan berdasarkan nilai rata-rata hasil belajar pada semester sebelumnya. Populasi dalam penelitian ini adalah siswa tingkat XI
MAAsy-syakur Nglingi Ngasem Kabupaten Bojonegoro tahun ajaran 2019/2020 sebanyak 40 orang, terdiri atas dua kelas yaitu kelas X IPA 2 dan X IPA 1. Alat ukur yang dginakan untuk pemberian nilai adalah dengan mengguankan tes tulis dan angket (kuisioner) untuk mengetahui keterlibatan dan keaktifan siswa. Sedangkan untuk penarikan sampel dalam penelitian ini dengan menggunakan teknik sampling purposive, yang digunakan dengan menentukan kriteria khusus terhadap sampel berupa hasil nilai raport semester ganjil. Analisis data yang digunakan berdasarkan tes awal (pretest) serta data hasil tes setelah diberi perlakuan atau post test. Uji hipotesis digunakan dengan menggunakan uji normalitas, uji homogenitas dan n-gain.

\section{HASIL DAN PEMBAHASAN}

Hasil penelitian didapat melalui tes pada materi memahami unsur-unsur hadist, yang dilakukan dua kali, yakni sebelum pembelajaran (pretest) dan setelah dilakukan pembelajaran (postest). Dengan menggunakan $\mathrm{N}$-gain, maka diperoleh hasil pembelajaran untuk kelas dengan menggunakan aplikasi Whatsapp lebih tinggi daripada dan kelas yang menggunakan Schoology, seperti yang terdapat pada tabel berikut:

Tabel 1. Table N-gain hasil belajar kelas Whatsapp dan kelas Schoology

\begin{tabular}{cc} 
Kelompok Kelas & $\begin{array}{c}\text { N-gain } \\
\text { Score }\end{array}$ \\
\hline Kelompok Schoology (IPA 1) & 0,44 \\
\hline KelompokWhatsapp (IPA 2) & 0,65 \\
\hline
\end{tabular}

Adapun hasil penelitain pada aspek afektif keaktifan siswa pada kelompok kelas dengan menggunakan Schoology (kelas X IPA 1) dalam mengajukan pertanyaan memiliki hasil persentase rendah yakni sebesar 56,82 \%, kesungguhan dalam mengerjakan soal sebesar $68,18 \%$, serta kemampuan siswa dalam mengemukakan pendapat sebesar $56,02 \%$. Adapaun untuk kelompok kelas dengan menggunakan 
Whatsapp (kelas X IPA 2) memiliki nilai prosesntase untuk kemampuan dalam mengajukan pertanyaan sebesr $75,92 \%$ ), kemampuan dalam menjawab pertanyaan sebesar $76,82 \%$ dan kemampuan dalam mengemukakan pendapat $71,82 \%$. Hal ini menunjukkan bahwa hasil kemandirian belajar siswa secara afektif untuk kelompok kelas dengan menggunakan aplikasi Whatsapp (kelas X IPA 2) lebih tinggi daripada kelompok kelas dengan menggunakan Schoology (kelas X IPA 1).

Terdapat tiga tahapan dalam penelitian ini yang akan dibahas, yaitu sebelum pembelajaran, saat pembelajaran dan setelah pembelajaran. Pada tahap pertama, dimana sebelum dilakukan pembelajaran, para siswa baik siswa di kelompok kelas aplikasi Whatsapp dan kelompok kelas Schoology diberikan tes. Hal ini dilakukan untuk mengetahui pemahaman awal para siswa terhadap materi yang akan diberikan dalam proses pembelajaran. Dimana diketahui bahwa rata-rata nilai tertinggi pre-test untuk kelas X IPA 2 adalah 23 dan nilai terendah untuk kelas X IPA 2 adalah 21,2 dan rata-rata nilainya sebesar 21,8. Sedangkan untuk kelas X IPA 1 memiliki nilai tertinggi 23,4 dan nilai terendah 21,6 dan untuk rata-rata nilainya sebesar 22,4. Hal ini menunjukkan terdapat perbedaan antara kelas X IPA 1 dan kelas X IPA 2, dimana untuk hasil nilai pre-test kelas $\mathrm{X}$ IPA 1 lebih tinggi dari IPA 1 dan kelas $\mathrm{X}$ IPA 2.

Adapun untuk hasil post-test setelah
dilakukan pembelajaran dengan
menggunakan aplikasi Whatsapp untuk
kelas X IPA 2 dan menggunakan Schoology
untuk kelas X IPA 1 maka hasilnya adalah
kelompok kelas Whatsaap memperoleh nilai
tetringgi 23,6 dan nilai terendah adalah 22,8
dengan rata-rata hasil nilai post-test sebesar
23,13. Sedangkan untuk kelas X IPA 1 yang
menggunakan shoology memiliki nilai
tertinggi 23,4 dan nilai terendah 22,8 dengan
rata-rata nilai post-test sebesar 22,9. Hal ini
menunjukkan adanya perbedaan nilai rata-
rata antara kelas Schoology dengan kelas
yang menggunakan aplikasi Whatsapp,
dimana kelas yang menggunakan aplikasi

Whatsapp lebih tinggi daripada kelas yang menggunakan Schoology, atau kelas X IPA 2 memiliki nilai rata-rata post-test lebih tinggi daripada kelas X IPA 1.

Penggunaan aplikasi Whatsaap dibandingkan penggunaan Schoology lebih mudah diterima oleh para siswa. Hal ini lantaran para siswa sudah familiar dengan aplikasi tersebut. Dibandingkan dengan Schoology, para siswa cenderung terbilang baru mengenal Schoology sehingga mereka harus mempelajari lagi cara mengoperasikan media pembelajaran berbasis web tersebut. Dengan penggunaan aplikasi Whatsapp, siswa dengan mudah melihat tayangan video yang guru kirimkan di grup kelas. Dari tayangan teersebut, para siswa saling memberikan komentar dan berdiskusi secara aktif di grup. Hal ini menunjukkan partisIPA 1 si siswa yang cukup aktif. Sementara untuk Schoology yang dianggap para siswa memiliki tampilan yang kurang menarik dan terkesan sangat formal, membuat mereka jarang membuka media berbasis web tersebut.

Meskipun pada dasaranya guru memberikan kesempatan seluas-luasnya kepada para siswa untuk menyampaikan ide dan gagasan serta mencari informasi tambahan penunjang pembelajaran dari berbagai media baik bagi siswa dengan kelompok kelas aplikasi whatsaap maupun pada siswa dengan kelompok kelas schooogy, tetapi antusias yang diberikan siswa berbeda. Kelompok kelas Schoology cenderung pasif dengan komentar dan gagasan yang diberikan lebih sedikit dibandingkan kelompok kelas aplikasi Whatsapp. Berbanding terbaik dengan kelompok kelas whatsaap, hampir semua peserta di grup aktif muncul untuk menyampaikan ide dan gagasan. Bahkan, di beberapa kesempatan, siswa yang pasif di pertemuan kelas justru terlihat sangat aktif berkomentar di grup Whatsapp. Senada dnegan hasil penelitian yang dilakukan oleh Susilo (2014) yang menyatakan bahwa paradigma proses pembelajaran dalam dunia pendidikan saat ini tidak hanya bias melalui pertemuan tatap muka di ruangan saja, tetapi juga dapat dilaksanakan secara daring (online) melalui internet dengan berbagai media aplikasi yang ada. 
Hambatan yang terjadi bagi para siswa kelompok kelas Schoology salah satunya adalah mereka kesulitan membuat akun di Schoology sebagai siswa. Terlebih, instruksi yang diberikan melalui daring. Beberapa diantara mereka masih beradaptasi dengan pembelajaran daring, terutama terkait dengan intruksi tanpa tatap muka. Sehingga kegiatan belajar secara mandiri juga mengalami kendala. Terlebih, para siswa terbilang baru dalam mengenal situs web bernama Schoology tersebut.

Sebagai catatan untuk kedepan, pembelajaran tidak hanya dilakukan di kelas saja. Melainkan penggunaan media social semisal aplikasi Whatsapp maupun pengembangan situs web dalam bidang pendidikan semisal Schoology layak untuk dimanfaatkan sebagai media pembelajaran. Hal sangat bagus untuk ke depan pembelajaran secara blended secara nyata dan virtual tentunya akan mampu meningkatkan pengalaman belajar oleh peserta didik setelah masa darurat pandemic

\section{SIMPULAN}

Berdasarkan hasil penelitian, dapat disimpulkan bahwa terdapat perbedaan antara siswa dengan kelompok kelas yang menggunakan aplikasi Whatsapp dengan siswa dengan kelompok kelas yang menggunakan situs berbasis web Schoology. Dimana kelompok kelas yang menggunakan aplikasi Whatsapp memiliki hasil nilai ratarata lebih tinggi dibandingkan kelompok kelas yang menggunakan situs berbasis web Schoology.

Adapun saran untuk ke depan apabila wabah pandemic berakhir, pembelajaran dengan menggabungkan proses pembelajaran secara nyata dan virtual hendaknya dilakukan dengan menemukan formula yang tepat dalam penggunaan bahan ajar dan model yang tepat sehingga menjadi proses pembelajaran yang menarik, interaktif, dan komunikatif dengan para siswa untuk mendapatkan umpan balik. berakhir. Sehingga ke depan, harapannya aka nada formulai yang lebih baik baik dalam pengelolaan media pembelajaran baik dalam hal bahan ajar maupun model yang tepat dalam pembelajaran kombinasi seperti ini. Penentuan topic-topik yang menarik dalam pembelajaran online juga harus dirancang sedemikian rupa supaya terjadi umpan balik yang baik antara guru dan para siswa. Hal ini menunjukkan bahwa pembelajaran bisa sangat menarik dan komunikatif tanpa kendala yang berarti. Artinya, guru mampu memberikan fasilitas pembelajaran baik di kelas maupun di luar kelas, baik pada jam pelajaran maupun di luar jam pelajaran, baik secara formal maupun informal. Dengan demikan para siswa akan berperan aktif terhadap proses belajar mengajar apabila ada notifikasi di ponsel mereka sehingga terjadi proses pembelajaran secara interaktif dan komunikatif.

\section{DAFTAR RUJUKAN}

Arsini. (2017). Penguatan Kompetensi dan Keterampilan Guru Madrasah Se-Kota Semarang dalam Mengembangkan "Web Based Assesment" Menggunakan Schoology. DIMAS Volume 17, Nomor 2, pp. 277 - 295.

Gheytasi, M., Azizifar, A., \& Gowhary, H. (2015). The Effect of Smartphone on the Reading Comprehension Proficiency of Iranian EFL Learners. Procedia - Social and Behavioral Sciences, $\quad 199, \quad 225-230$. https://doi.org/10.1016/J.SBSPRO.201 5.07.510.

Indaryani, Eka dan Sulisworo, D. (2018). Dampak pemanfaatan Whatsapp dalam meningkatkan motivasi belajar pada materi fisika. Papers Seminar Nasioanal Quantum. 25-30.

Irwandani, S.J. (2016). Pengembangan media pembelajaran berupa komik fisika berbantuan media sosial 
instagram sebagai alternatif. J.Ilmiah Pendidikan Fisika, 5 (1), pp. 33 - 42.

Muclas. (2016). Blended learning berbasis kontruktivisme untuk pembelajaran praktik di perguruan tinggi teknik. Seminar Nasional Vokasi dan Teknologi (SEMNASVOKTEK). Pp. 61 -76 .

Nugroho, R. Setiawan Aji. (2020). BRDBeratkah untuk orang IT? : 21 Refleksi Pembelajaran Daring Di Masa Darurat. Universitas Katolik Segijapranata: Semarang.

Pratikno, Teguh \& Ewo Termedi, Wahid Munawar. (2014). Studi Komparasi Hasil Belajar Siswa Yang Menggunakan Aurora 3 Dimensi Presentation Dengan Siswa Yang Menggunakan Media Engine Trainer Pada Kompetensi Menjelaskan Konsep Motor Bakar. Journal of Mechanical Engineering Education, Vol.1, No.1, pp: $146-153$.

Putrawangsa, S., \& Hasanah, U. (2018). Integrasi Teknologi Digital Dalam Pembelajaran Di Era Industri 4.0. Jurnal Tatsqif, 16(1), pp. 42-54. Retrieved from http://journal.uinmataram.ac.id/index.p hp/tatsqif/article/view/203

Rambe, P. dan Bere, A. (2013). Using mobile instant messaging to leverage learner partic IPA 1tion and transform pedagogy at a south african university of technology. J. Educational Technology, 44 (4): $1-6$.

Rambe, P. dan Chipunza, C. (2013). Using Devices to Leverage Student Access to Collaboratively Generated Resources: A Case of Whatsapp Instant Messaging at a Suoth African University. Internasional Conference on Advanced Information and Communication Technology for Education (ICAICTE 2013). Pp. 331-337.

Sanjaya, Ridwan. (2020). Bahtera Dunia Pendidikan Di Masa Darurat Pandemi: 21 Refleksi Pembelajaran Daring Di Masa Darurat. Universitas Katolik Segijapranata: Semarang.

Sholihatin \& Wayan Suana, Feriansyah Sesunan. (2019). Pengaruh Pemanfaatan Mobile Instant Messaging (Mim) Pada Pembelajaran Materi Hukum Newton Terhadap Kemampuan Berpikir Tingkat Tinggi. Jurnal Tarbawi: Jurnal Ilmu Pendidikan Vol. 15, No. 01, Juli 2019, pp. 1-10.

Susilo, Adhi. (2014). Using facebook and Whatsapp to leverage learner partic IPA 1tion and transform pedadogy at the open University of Indonesia. $J$. Pendidikan Terbuka dan Jarak Jauh, 15 (2): $63-80$. 